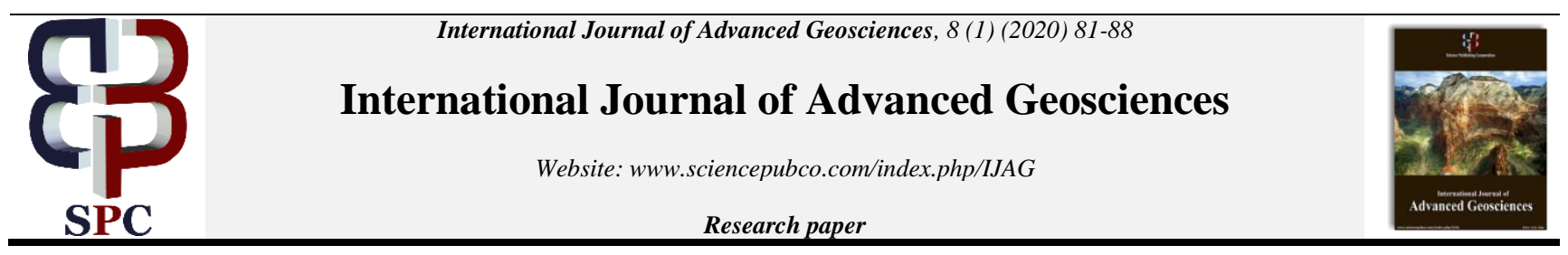

\title{
Trend analysis of rainfall data Rangpur, Bangladesh
}

\author{
Sudip Saha * \\ Department of Geology and Mining, University of Rajshahi, Rajshahi-6205, Bangladesh \\ *Corresponding author E-mail: sudips_geologist@yahoo.com
}

\begin{abstract}
The study area lies in Bangladesh that is in the tropical area. The analysis of rainfall data reveals that the average annual rainfall in Rangpur was $2099.25 \mathrm{~mm}$ that varies from $427 \mathrm{~mm}$ to $3748 \mathrm{~mm}$ within the investigated period of time. The highest amount of annual rainfall was recorded in 1984. Heavy rainfall occurs in the month of July of the year. The highest amount of total monthly rainfall was recorded in July, 1987 and measured as $1314 \mathrm{~mm}$. The rainfall trend can be expressed as monsoon rainfall > pre-monsoon rainfall> post monsoon rainfall. The total amount of annual rainfall is strongly significantly positively correlated with the total monthly rainfall of the months of June, July August, September and October and significantly positively correlated with the total monthly rainfall of the month April. The analysis shows that it rained in every year in the month of June as the minimum monthly value for June is greater than zero. Pearson correlation index shows that the mean daily temperature is significantly negatively correlated with daily rainfall which implies that fall of daily mean temperature with the daily rainfall. The increasing trend of annual rainfall suggests the climate change in Rangpur within the investigated period of time. In Rangpur, the value of skewness for all rainfall data are positive that indicate the data are skewed to the right. The positive values of kurtosis indicate that the distribution is not normal.
\end{abstract}

Keywords: Annual Rainfall; Climate Change; Pearson; Monsoon and Rangpur.

\section{Introduction}

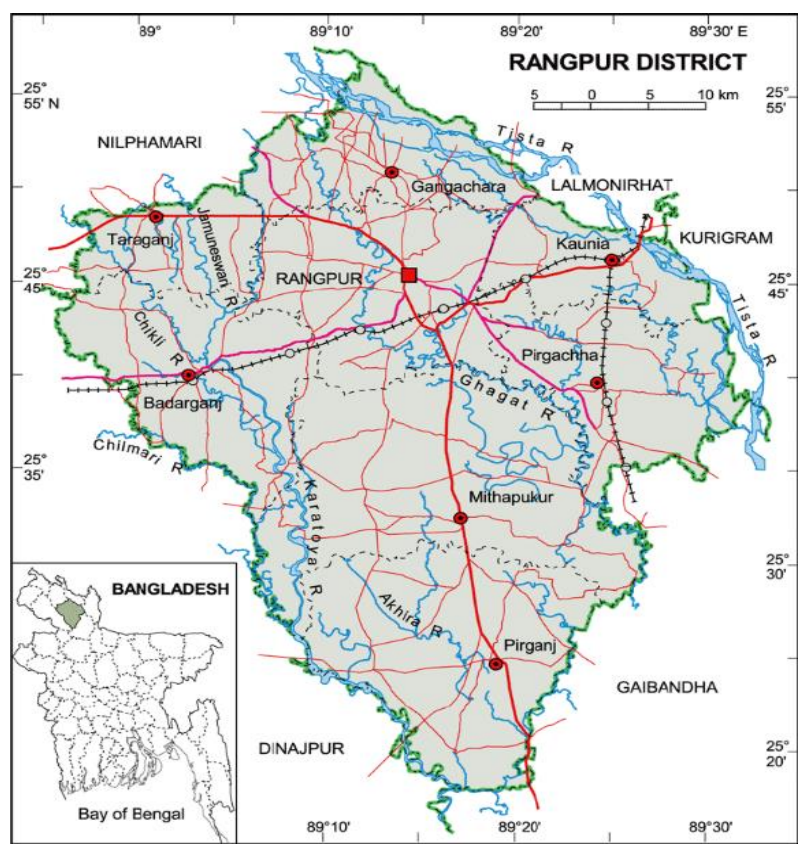

Fig. 1: Map of the Study Area, Rangpur, Bangladesh.

Rainfall is the major form of precipitation in Bangladesh. The rainfall is one of the principal factors that control the agriculture, health condition and life style of people of any region (Islam et al. 2019). Sometimes excess rainfall becomes curse for the people of Bangladesh. The study area Rangpur lies in the northern part of Bangladesh (Figure 1) and is characterized by heavy rainfall during the summer and low rainfall during pre-monsoon and post monsoon periods (Rahman et al. 2016). Rainfall is the main input of the hydrogeological cycle 
of the study area. The climate change is measured by the rainfall patterns where Bangladesh is considered as one of the most vulnerable countries to climate change (IPCC 2007: Richard 2012).

The study area is drained by numerous rivers like Tista, Ghagat, Jamuneswari and Karatoa. It is the extension of the Himalayan piedmont plain that slope southward (Saha et al. 2020). The surface geology is mainly composed of gravel, sand, silt and clay of Recent age and in some areas by the clay deposits of Pleistocene age.

The present research work deciphers the total monthly rainfall and trend of annual rainfall. The annual rainfall is mainly influence by the monsoon wind. The daily rainfall also helps to lower the daily temperature especially in monsoon summer. The amount of annual rainfall shows positive correlation with time.

\section{Methods}

Daily rainfall data of Rangpur, Bangladesh was downloaded from website. From the daily rainfall data, total monthly rainfall was calculated using necessary computer software. The total annual rainfall was calculated by adding the total monthly rainfalls of twelve months of that specific year. The mean monthly rainfall and mean annual rainfall were analyzed. The required graphs were drawn. The Pearson correlation coefficients were calculated. The other statistical parameters such as mean, median standard deviation, skewness and kurtosis were calculated to analyze the yearly and monthly data (Islam et al. 2019). The daily rainfall data of the wettest month of July, 1987 were correlated with the mean daily temperature to show the influence of daily rainfall on daily mean temperature.

\section{Results}

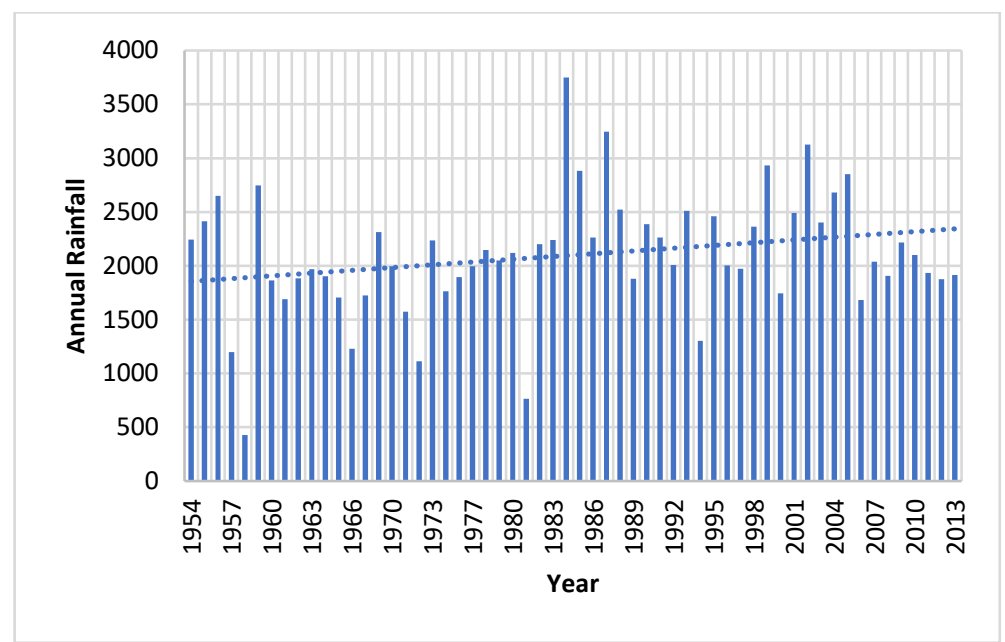

Fig. 2: Annual Trend of Rainfall in mm in Rangpur 1954-2013.

Figure 2: Shows The Distribution of Total Annual Rainfall of Rangpur Station During 1954-2013.The analysis of rainfall data reveals that the average annual rainfall in Rangpur during this period was $2099.25 \mathrm{~mm}$. The highest amount of annual rainfall was recorded as 3748 $\mathrm{mm}$ in the year of 1984, while the lowest amount of annual rainfall was $427 \mathrm{~mm}$ in the year of 1958 . The total amount of annual rainfalls was higher than 3000mm in the years of 1984, 1987and 2002 in Rangpur (Figure 2). Figure 2 and Table 2 depict that the amount of total annual rainfall is positively correlated with time. The analyses of daily rainfall data reveal the maximum amount of daily rainfall was 294 $\mathrm{mm}$ in September 25, 2002. The heaviest rainfall in any given month during the study period was recorded in July, 1987.

Table 1: Statistical Summary of Monthly Rainfall Data of Rangpur

\begin{tabular}{|c|c|c|c|c|c|c|c|c|c|c|c|c|}
\hline Parameter & Jan & Feb & Mar & Apr & May & Jun & Jul & Aug & Sep & Oct & Nov & Dec \\
\hline Mean (mm) & 8.45 & 9.14 & 27.36 & 92.17 & 263.47 & 440.55 & 447.1 & 328.24 & 309.83 & 158.84 & 7.64 & 7.21 \\
\hline Median (mm) & 3 & 3.5 & 8.5 & 74.5 & 270.5 & 426.5 & 460 & 332.5 & 306.5 & 121 & 1 & 0 \\
\hline $\mathrm{SD}(\mathrm{mm})$ & 11.35 & 13 & 42.72 & 76.73 & 102.29 & 190.14 & 219.27 & 187.99 & 178.83 & 144.96 & 17.14 & 17.17 \\
\hline Variance & 128.7 & 169 & 1825.3 & 5887.7 & 10464 & 36154.6 & 48080.4 & 35338.5 & 31979.6 & 21014.1 & 293.9 & 294.8 \\
\hline Skewness & 1.63 & 1.89 & 3.3 & 1.27 & 0.02 & 0.8 & 0.99 & 0.49 & 0.53 & 1.36 & 4.21 & 3.68 \\
\hline Kurtosis & 2.44 & 3.42 & 14.52 & 2.27 & 0.34 & 1.15 & 3.28 & 0.21 & 0.05 & 1.4 & 21.74 & 16.91 \\
\hline $\operatorname{Max}(\mathrm{mm})$ & 49 & 57 & 257 & 376 & 545 & 989 & 1314 & 832 & 804 & 586 & 109 & 103 \\
\hline $\operatorname{Min}(\mathrm{mm})$ & 0 & 0 & 0 & 0 & 0 & 104 & 0 & 0 & 0 & 0 & 0 & 0 \\
\hline Range (mm) & 49 & 57 & 257 & 376 & 545 & 885 & 1314 & 832 & 804 & 586 & 109 & 103 \\
\hline Sum (mm) & 490 & 530 & 1587 & 5346 & 15281 & 25552 & 25932 & 19038 & 17970 & 9213 & 443 & 418 \\
\hline
\end{tabular}

Table 1 shows the distribution of mean monthly rainfall of Rangpur station during 1954-2013. Figure 3 shows that $80.21 \%$ annual rainfall occurs during the monsoon months of June-October, while $18.67 \%$ annual rainfall occurs in the pre-monsoon months of February-May and $1.11 \%$ annual rainfall was recorded in post monsoon periods November-January. 


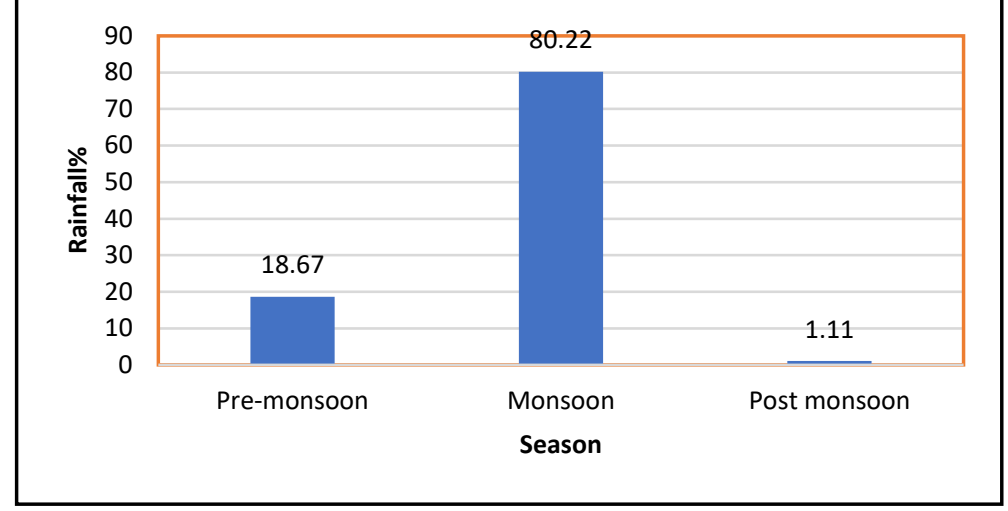

Fig. 3: Distribution of Rainfall in Different Seasons

Table 2: Detailed Statistical Summary of Annual Rainfall Data of Rangpur

\begin{tabular}{|c|c|c|c|c|c|c|c|c|c|c|}
\hline Year & $\begin{array}{l}\text { Annual } \\
(\mathrm{mm})\end{array}$ & $\begin{array}{l}\text { Mean } \\
(\mathrm{mm})\end{array}$ & $\begin{array}{l}\text { Median } \\
(\mathrm{mm})\end{array}$ & $\begin{array}{l}\text { SD } \\
(\mathrm{mm})\end{array}$ & $\begin{array}{l}\text { Variance } \\
(\mathrm{mm})\end{array}$ & Skewness & Kurtosis & $\begin{array}{l}\text { Max. } \\
(\mathrm{mm})\end{array}$ & $\begin{array}{l}\text { Min. } \\
(\mathrm{mm})\end{array}$ & $\begin{array}{l}\text { Range } \\
(\mathrm{mm})\end{array}$ \\
\hline 1954 & 2243 & 186.9 & 55.0 & 297.4 & 88466.6 & 1.9 & 3.3 & 944 & 0 & 944 \\
\hline 1955 & 2414 & 201.2 & 37.5 & 300.2 & 90100.7 & 1.5 & 1.2 & 892 & 0 & 892 \\
\hline 1956 & 2650 & 220.8 & 80.5 & 265.4 & 70454.0 & 0.9 & -0.4 & 769 & 0 & 769 \\
\hline 1957 & 1199 & 99.9 & 5.0 & 157.4 & 24790.1 & 1.4 & 0.7 & 439 & 0 & 439 \\
\hline 1958 & 427 & 35.6 & 0.0 & 69.1 & 4776.4 & 1.9 & 2.1 & 188 & 0 & 188 \\
\hline 1959 & 2748 & 229.0 & 180.0 & 210.4 & 44275.1 & 0.7 & -0.8 & 586 & 0 & 586 \\
\hline 1960 & 1864 & 155.3 & 73.5 & 190.7 & 36355.9 & 0.9 & -0.8 & 488 & 0 & 488 \\
\hline 1961 & 1717 & 143.1 & 99.0 & 153.4 & 23528.4 & 0.8 & -0.7 & 440 & 0 & 440 \\
\hline 1962 & 1882 & 156.8 & 37.5 & 209.3 & 43817.1 & 1.1 & -0.3 & 572 & 0 & 572 \\
\hline 1963 & 1967 & 163.9 & 73.5 & 187.2 & 35050.6 & 1.1 & 0.2 & 566 & 0 & 566 \\
\hline 1964 & 1902 & 158.5 & 104.0 & 190.9 & 36453.9 & 1.2 & 0.5 & 554 & 0 & 554 \\
\hline 1965 & 1708 & 142.3 & 50.5 & 179.9 & 32366.2 & 1.3 & 0.9 & 553 & 0 & 553 \\
\hline 1966 & 1231 & 102.6 & 36.5 & 126.1 & 15894.3 & 1.0 & -0.7 & 324 & 0 & 324 \\
\hline 1967 & 1723 & 143.6 & 144.5 & 148.7 & 22119.9 & 1.1 & 0.8 & 474 & 0 & 474 \\
\hline 1969 & 2313 & 192.8 & 71.5 & 212.7 & 45256.4 & 0.9 & -0.3 & 636 & 0 & 636 \\
\hline 1970 & 1997 & 166.4 & 39.0 & 209.1 & 43707.4 & 1.0 & -0.8 & 527 & 0 & 527 \\
\hline 1971 & 1573 & 131.1 & 30.5 & 169.6 & 28777.5 & 0.9 & -0.8 & 438 & 0 & 438 \\
\hline 1972 & 1114 & 92.8 & 47.5 & 108.4 & 11746.0 & 1.1 & 0.3 & 325 & 0 & 325 \\
\hline 1973 & 2237 & 186.4 & 58.5 & 246.4 & 60727.0 & 1.4 & 1.0 & 744 & 4 & 740 \\
\hline 1975 & 1763 & 146.9 & 119.5 & 170.3 & 28998.3 & 1.0 & -0.1 & 468 & 0 & 468 \\
\hline 1976 & 1895 & 157.9 & 85.0 & 192.0 & 36855.0 & 0.9 & -0.8 & 500 & 0 & 500 \\
\hline 1977 & 1996 & 166.3 & 120.5 & 187.3 & 35080.1 & 0.9 & -0.3 & 550 & 0 & 550 \\
\hline 1978 & 2145 & 178.8 & 105.0 & 204.9 & 41998.9 & 0.8 & -0.9 & 530 & 0 & 530 \\
\hline 1979 & 2048 & 170.7 & 87.5 & 220.3 & 48542.6 & 1.5 & 1.5 & 677 & 0 & 677 \\
\hline 1980 & 2120 & 176.7 & 53.0 & 205.8 & 42366.6 & 0.8 & -0.8 & 579 & 0 & 579 \\
\hline 1981 & 763 & 63.6 & 11.5 & 124.5 & 15506.6 & 2.8 & 8.1 & 432 & 0 & 432 \\
\hline 1982 & 2201 & 183.4 & 81.5 & 232.1 & 53876.1 & 1.0 & -0.5 & 649 & 0 & 649 \\
\hline 1983 & 2238 & 186.5 & 152.0 & 198.8 & 39505.9 & 1.0 & 0.7 & 636 & 0 & 636 \\
\hline 1984 & 3748 & 312.3 & 144.0 & 358.9 & 128841.0 & 0.8 & -0.8 & 989 & 0 & 989 \\
\hline 1985 & 2882 & 240.2 & 182.0 & 250.8 & 62921.2 & 0.9 & 0.1 & 770 & 0 & 770 \\
\hline 1986 & 2264 & 188.7 & 151.0 & 189.2 & 35809.0 & 0.5 & -1.2 & 518 & 0 & 518 \\
\hline 1987 & 3247 & 270.6 & 119.5 & 381.3 & 145410.6 & 2.1 & 5.0 & 1314 & 0 & 1314 \\
\hline 1988 & 2524 & 210.3 & 101.0 & 227.2 & 51625.5 & 0.7 & -1.0 & 633 & 0 & 633 \\
\hline 1989 & 1878 & 156.5 & 33.0 & 227.5 & 51767.0 & 1.7 & 2.4 & 719 & 0 & 719 \\
\hline 1990 & 2386 & 198.8 & 179.0 & 172.3 & 29693.4 & 0.1 & -1.8 & 439 & 0 & 439 \\
\hline 1991 & 2263 & 188.6 & 73.5 & 243.9 & 59472.8 & 1.4 & 1.1 & 726 & 1 & 725 \\
\hline 1992 & 2007 & 167.3 & 109.0 & 183.7 & 33746.0 & 0.9 & -0.1 & 552 & 0 & 552 \\
\hline 1993 & 2510 & 209.2 & 76.5 & 239.7 & 57475.6 & 0.9 & -1.0 & 633 & 0 & 633 \\
\hline 1994 & 1301 & 108.4 & 73.0 & 124.4 & 15470.8 & 1.7 & 3.2 & 427 & 0 & 427 \\
\hline 1995 & 2461 & 205.1 & 80.0 & 268.1 & 71865.9 & 1.3 & 0.8 & 804 & 1 & 803 \\
\hline 1996 & 2004 & 167.0 & 99.0 & 182.9 & 33443.8 & 0.5 & -1.5 & 479 & 0 & 479 \\
\hline 1997 & 1971 & 164.3 & 70.0 & 184.8 & 34139.7 & 0.8 & -0.7 & 523 & 2 & 521 \\
\hline 1998 & 2365 & 197.1 & 187.5 & 186.8 & 34905.7 & 0.3 & -1.6 & 473 & 0 & 473 \\
\hline 1999 & 2931 & 244.3 & 265.5 & 257.9 & 66510.9 & 0.9 & 0.8 & 829 & 0 & 829 \\
\hline 2000 & 1745 & 145.4 & 92.5 & 165.9 & 27527.0 & 0.8 & -0.8 & 438 & 0 & 438 \\
\hline 2001 & 2492 & 207.7 & 136.5 & 219.6 & 48227.3 & 0.4 & -1.7 & 550 & 0 & 550 \\
\hline 2002 & 3127 & 260.6 & 193.0 & 293.6 & 86193.5 & 1.1 & 0.6 & 913 & 0 & 913 \\
\hline 2003 & 2402 & 200.2 & 151.5 & 213.0 & 45349.2 & 1.2 & 0.5 & 633 & 0 & 633 \\
\hline 2004 & 2680 & 223.3 & 164.5 & 229.5 & 52677.9 & 0.6 & -1.0 & 653 & 0 & 653 \\
\hline 2005 & 2853 & 237.8 & 182.0 & 242.4 & 58752.9 & 0.6 & -1.1 & 671 & 0 & 671 \\
\hline 2006 & 1682 & 140.2 & 90.5 & 160.1 & 25628.5 & 1.0 & 0.0 & 472 & 0 & 472 \\
\hline 2007 & 2037 & 169.8 & 92.5 & 205.5 & 42236.4 & 1.3 & 0.5 & 568 & 0 & 568 \\
\hline 2008 & 1907 & 158.9 & 124.5 & 156.8 & 24598.1 & 0.6 & -0.8 & 444 & 0 & 444 \\
\hline 2009 & 2217 & 184.8 & 117.5 & 242.2 & 58652.8 & 1.9 & 4.3 & 832 & 0 & 832 \\
\hline 2010 & 2102 & 175.2 & 145.5 & 200.3 & 40134.0 & 1.2 & 1.5 & 650 & 0 & 650 \\
\hline 2011 & 1932 & 161.0 & 24.0 & 198.0 & 39194.2 & 0.8 & -1.0 & 542 & 0 & 542 \\
\hline 2012 & 1877 & 156.4 & 122.0 & 171.7 & 29483.4 & 0.6 & -1.2 & 445 & 0 & 445 \\
\hline 2013 & 1916 & 159.7 & 172.0 & 151.2 & 22855.9 & 0.1 & -1.9 & 383 & 0 & 383 \\
\hline
\end{tabular}


January: The mean monthly rainfall for the month of January is $8.45 \mathrm{~mm}$ in the study area, while the total rainfall varies from $0 \mathrm{~mm}$ to 49 $\mathrm{mm}$ (Figure 4). It did not rain 22 years in the month of January in Rangpur. The mean monthly rainfall has a decreasing trend with time (years).

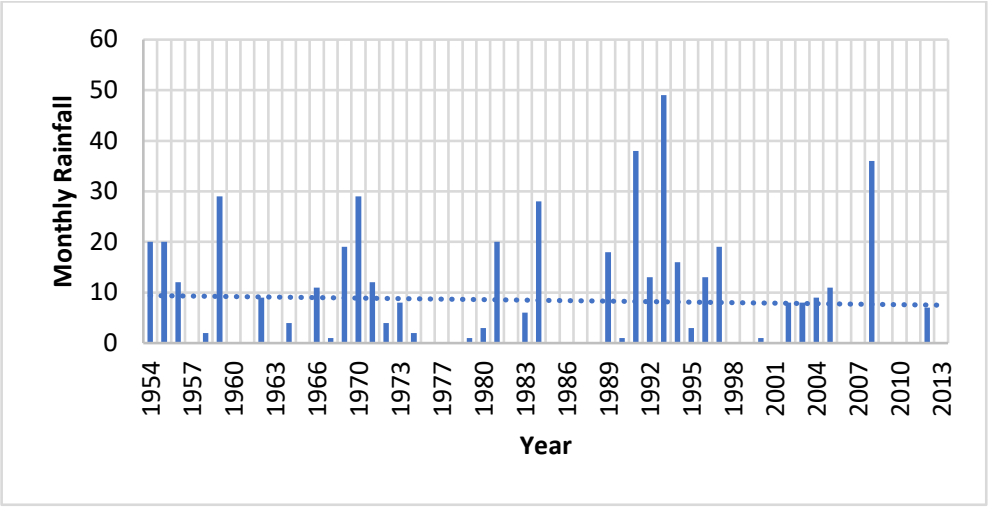

Fig. 4: January Rainfall in mm in Rangpur 1954-2013.

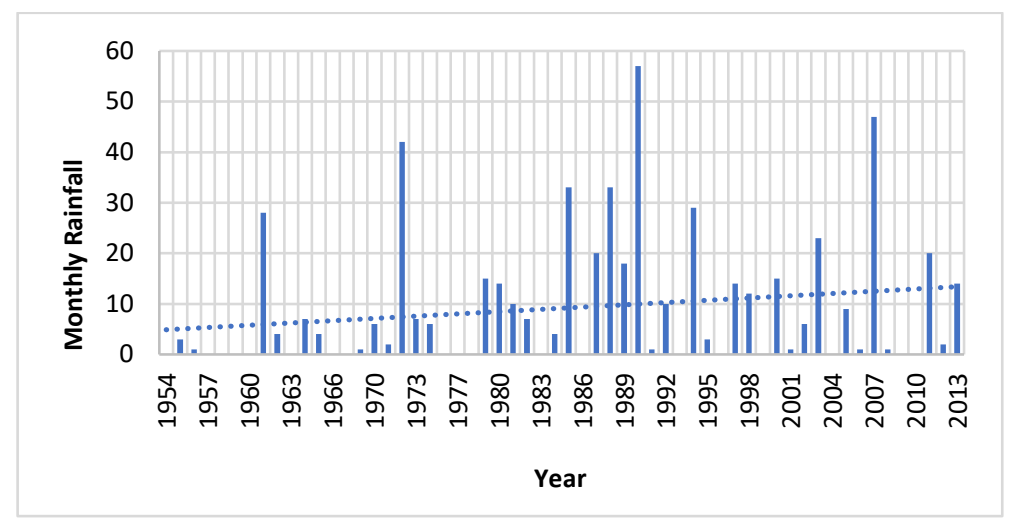

Fig. 5: February Rainfall in mm in Rangpur 1954-2013.

February: The total amount of rainfall varies from $0 \mathrm{~mm}$ to $57 \mathrm{~mm}$ for the month of February (Figure 5). The mean monthly rainfall for the month of February is $9.145 \mathrm{~mm}$ in the study area, while it did not rain 19 years in the month of February in Rangpur. The mean monthly rainfall of this month is increasing with time (years).

March: The total amount of rainfall during the month of March was highest in 1959 that was recorded as 257 mm (Figure 6). There was no rainfall during the month of March in seven years like 1954, 1957, 1971, 1977, 1992, 1996 and 2010. The total monthly rainfall for the month of March is negatively correlated with time. The mean monthly rainfall of March is $27.36 \mathrm{~mm}$.

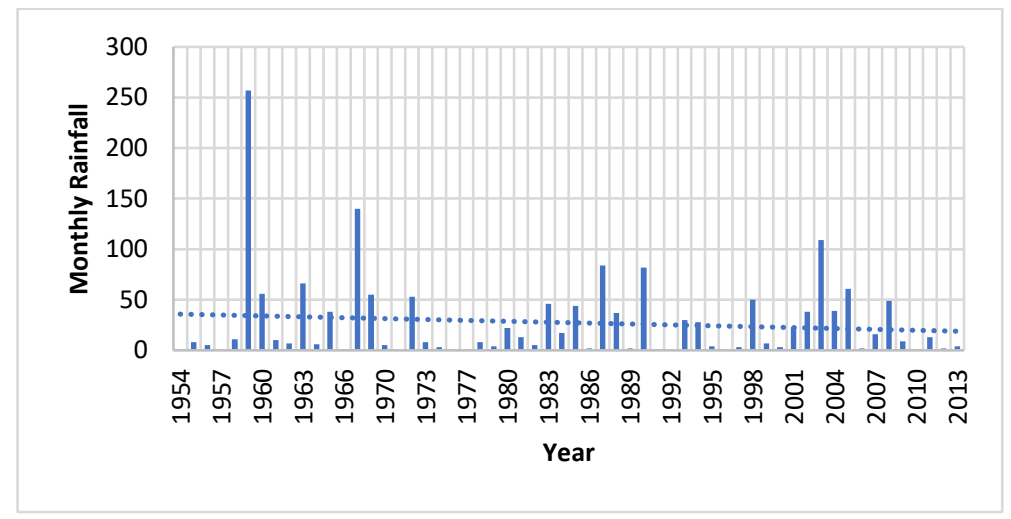

Fig. 6: March Rainfall in mm in Rangpur 1954-2013. 


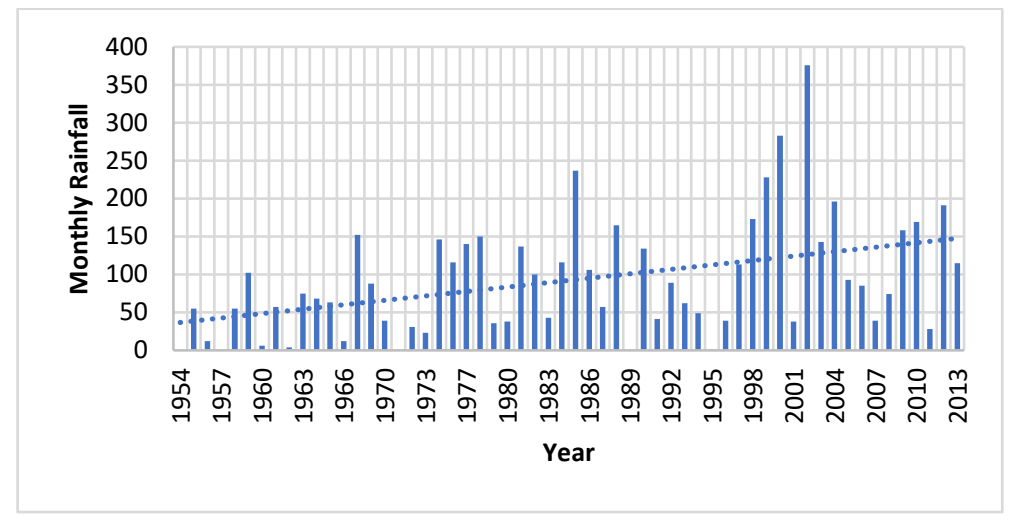

Fig. 7: April Rainfall in mm in Rangpur 1954-2013.

April: The amount of rainfall in the month of April starts to increase that is resulted by the higher amount of evaporations from the Bay of Bengal. Highest amount of total rainfall in the month of April was reported from the year 2002 whose numerical value was $376 \mathrm{~mm}$. The mean monthly value for the month of April was $92.17 \mathrm{~mm}$. There was no rainfall in April for the years of 1954, 1957, 1971 and 1989. The amount of rainfall is positively correlated with time (Figure 7).

May: The maximum amount of rainfall of May was $545 \mathrm{~mm}$ which was recorded in 1984. The average value of rainfall of May is 263.46 $\mathrm{mm}$. The median value of rainfall is $270 \mathrm{~mm}$. The amount of rainfall is always higher than $70 \mathrm{~mm}$ except that of 1971. The magnitude of rainfall slightly increasing in expense of time (Figure 8). The increased amount of May rainfall might have influence by the increased amount of evaporation from the irrigated farmland in the study area.

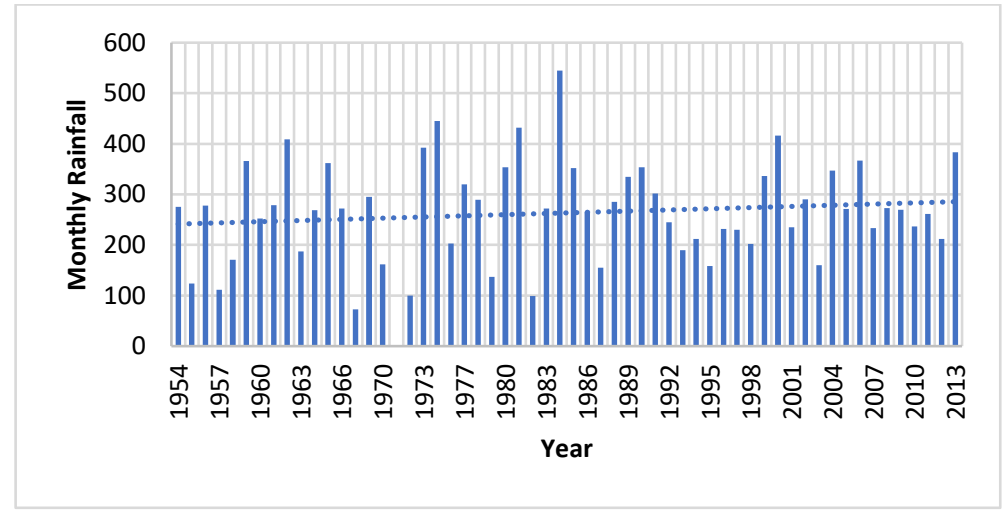

Fig. 8: May Rainfall in mm in Rangpur 1954-2013.

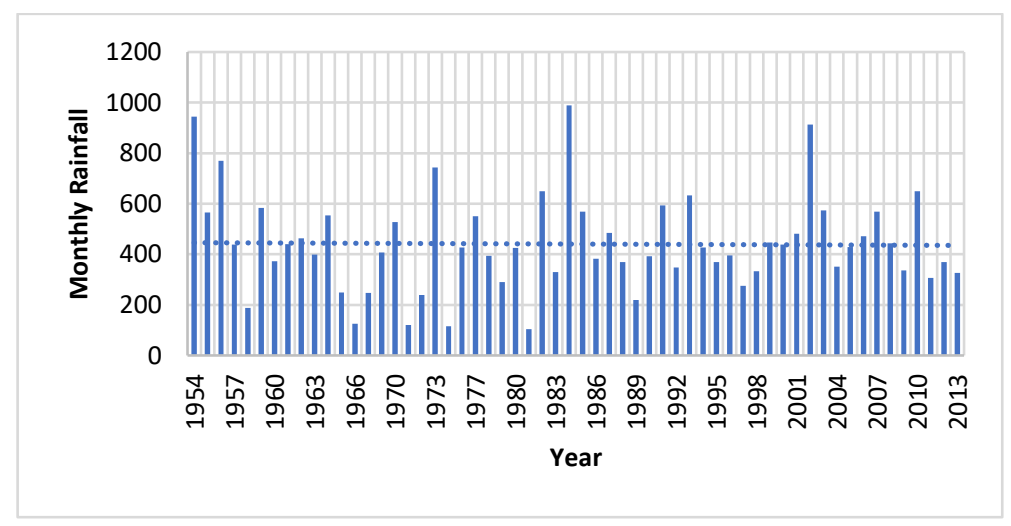

Fig. 9: June Rainfall in mm in Rangpur 1954-2013.

June: The amount of June rainfall varies from $104 \mathrm{~mm}$ to $989 \mathrm{~mm}$ with the mean rainfall value of $440.55 \mathrm{~mm}$. The median value for the June rainfall is $426.5 \mathrm{~mm}$. The distribution of total amount of rainfall remained even for the investigated time period in Rangpur (Figure 9). The maximum amount of June rainfall was reported in the year of 1984.

July: July is the wettest month of the year. The total amount of July rainfall remained more or less uniform over time (Figure 10). It did not rain only two years (1958 and 1981) in the month of July. The median July rainfall value is $460 \mathrm{~mm}$ (Table 1). The average magnitude is $447.10 \mathrm{~mm}$ while the highest amount of July rainfall was $1314 \mathrm{~mm}$ in the year of 1987. 


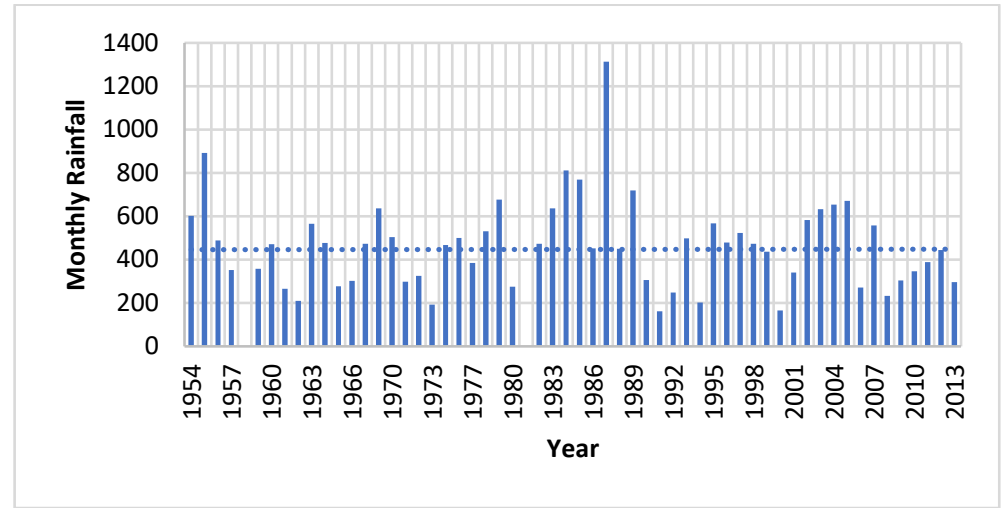

Fig. 10: July Rainfall in mm in Rangpur 1954-2013.

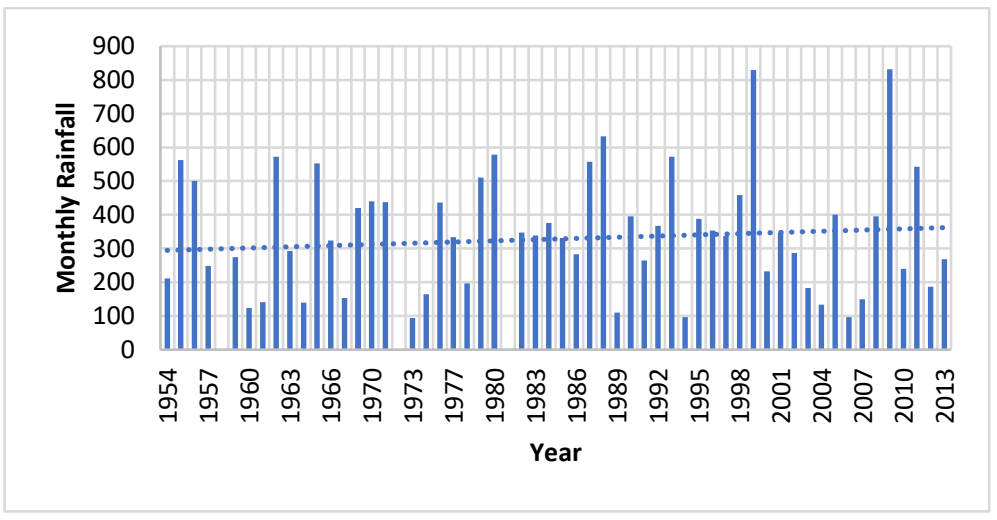

Fig. 11: August Rainfall in mm in Rangpur 1954-2013.

August: The maximum amount of August rainfall was $832 \mathrm{~mm}$ in the year of 2009 and lowest rainfall was $94 \mathrm{~mm}$ in 1973 (Figure 11 ). The amount of rainfall starts to decrease in August. The mean rainfall for the month of August was 328.24 mm while the median value is $332.5 \mathrm{~mm}$. The August rainfall is positively correlated with time.

September: The median value of September rainfall is $306.5 \mathrm{~mm}$ while the mean value is $309.83 \mathrm{~mm}$. The magnitude of September rainfall is increasing in expense of time (Figure 12). The maximum September rainfall was $804 \mathrm{~mm}$ in 1995 while least amount of rainfall was 38 $\mathrm{mm}$ in 1957.

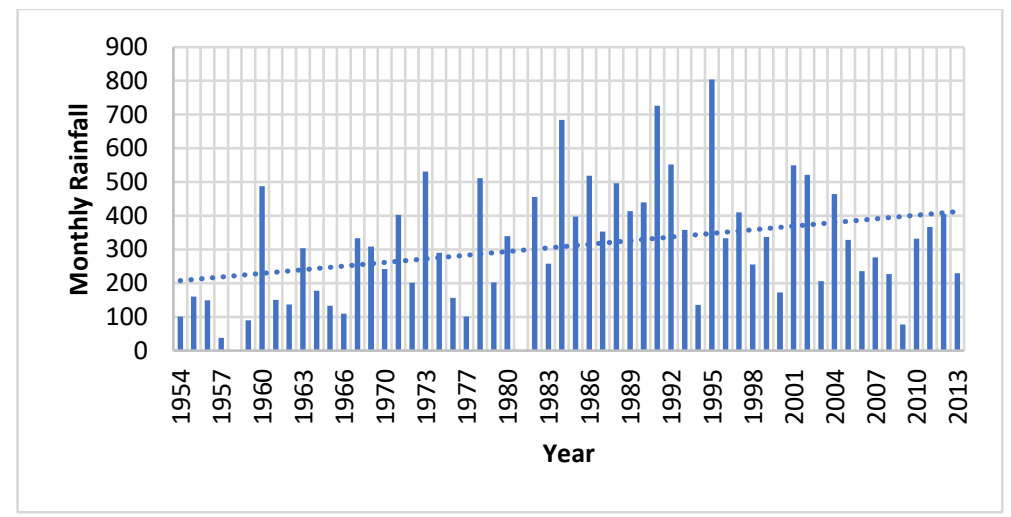

Fig. 12: September Rainfall in mm in Rangpur 1954-2013.

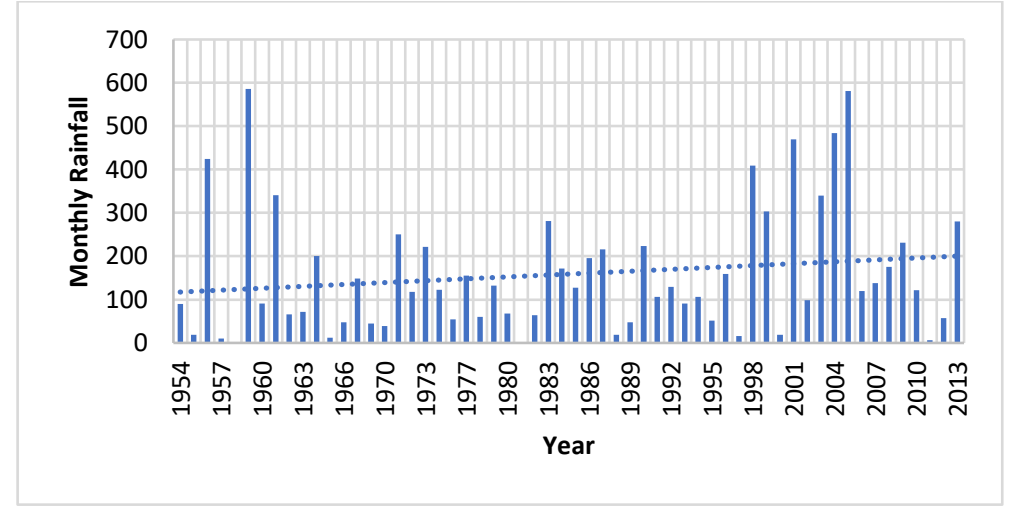

Fig. 13: October Rainfall in mm in Rangpur 1954-2013. 
October: The frequency of October rainfall is significantly marked by the decrease of mean value. The total amount of October rainfall varies from $6 \mathrm{~mm}$ (2011) to maximum $586 \mathrm{~mm}$ in 1959. The average value of October rainfall was $158.84 \mathrm{~mm}$ and the median value was $121 \mathrm{~mm}$. The amount of October rainfall is positively correlated with time (Figure 13).

November: The mean rainfall value of November was $7.64 \mathrm{~mm}$. The median was $1 \mathrm{~mm}$. The maximum amount of rainfall in November was $109 \mathrm{~mm}$ in 1995 while there was no rainfall in 27 years (Figure 14). The rainfall pattern was almost steady over the period of investigation in Rangpur.

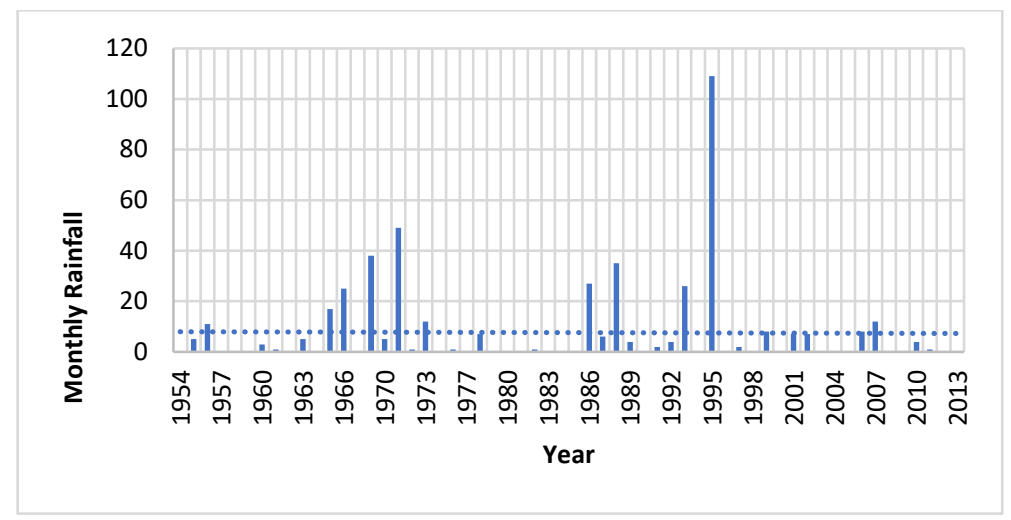

Fig. 14: November Rainfall in mm in Rangpur 1954-2013.

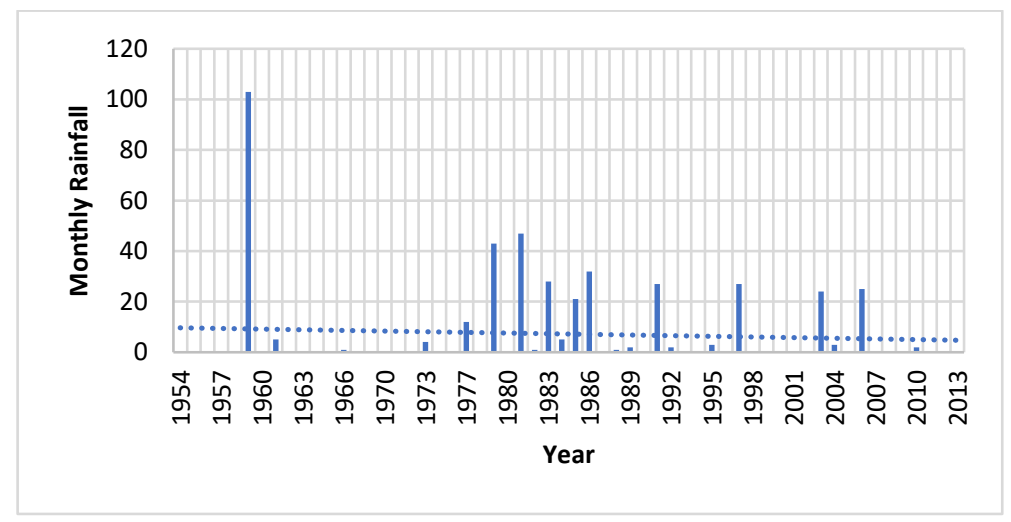

Fig. 15: December Rainfall in mm in Rangpur 1954-2013

December: The median value of December rainfall was $0 \mathrm{~mm}$ whereas the mean rainfall was $7.21 \mathrm{~mm}$. There was no rainfall in 36 years in the month of December. The maximum amount of rainfall was recorded in the year of 1959 which was $103 \mathrm{~mm}$. The pattern of December rainfall is decreasing with time (Figure 15).

Statistical Analysis of Rainfall

Table 1 shows the results of statistical analyses of rainfall data in millimeters. The amount of rainfall starts to increase from the month of March, reaches to the peak in July and then begins to fall. The highest total monthly rainfall was recorded in July 1987 that was $1314 \mathrm{~mm}$. Most of the rainfall occur in the months of May, June, July, August, September and October. The analysis shows that it rained in every year in the month of June as the minimum monthly value for June is greater than zero. The standard deviation and range describe the variability of annual rainfall and signify how reliable the rainfall in terms of its persistence as constant and stable replenishing source (Islam 2019). A high standard deviation value means that the rainfall is spread wide on the either sides of the mean.

Skewness and kurtosis were computed to test the pattern of annual rainfall data. The skewness for a normal distribution is zero, and any symmetrical data should have skewness value close to zero. Negative skewness values indicate that the data are skewed to the left while the positive skewness values suggest that the data are skewed to the right. In Rangpur, the value of skewness for all rainfall data are positive that indicate the data are skewed to the right.

Kurtosis is a measure of peakedness or flatness to normal distribution. The positive value of kurtosis means a peaked distribution and a negative value reveals the flat distribution with the same mean and standard deviation. The annual rainfall distribution under this circumstance, did not follow the normal distribution.

\section{Discussion}

The rainfall varies in different months of the year. The amount of rainfall influences the agricultural activities of a region. The analysis of rainfall data is important for proper crop management. The rainfall also controls the hydrogeological characters of an area. In Rangpur region, the water from the rainfall recharge the groundwater aquifer, surface water bodies and the quality of groundwater and surface water bodies depends on the recharge and discharge of them. The aquifers of Rangpur have the highest transmissivity in Bangladesh that vary from 1000-7000 square meters/day (UNDP 1982: Hussain and Abdullah 2001: Saha et al. 2019)). 
Table 3: Pearson Correlation Coefficient Matrix of Total Monthly Rainfall and Total Annual Rainfall (N=58)

\begin{tabular}{|c|c|c|c|c|c|c|c|c|c|c|c|c|c|}
\hline & Jan & Feb & Mar & Apr & May & Jun & Jul & Aug & Sep & Octo & Nov & Dec & Total \\
\hline Jan & 1.000 & & & & & & & & & & & & \\
\hline Feb & -0.218 & 1.000 & & & & & & & & & & & \\
\hline Mar & 0.116 & 0.127 & 1.000 & & & & & & & & & & \\
\hline Apr & -0.200 & 0.056 & 0.135 & 1.000 & & & & & & & & & \\
\hline May & 0.083 & 0.015 & -0.042 & $0.280^{*}$ & 1.000 & & & & & & & & \\
\hline Jun & $0.271^{*}$ & -0.080 & 0.032 & 0.138 & 0.182 & 1.000 & & & & & & & \\
\hline Jul & -0.004 & 0.050 & 0.173 & 0.051 & -0.179 & $0.282^{*}$ & 1.000 & & & & & & \\
\hline Aug & 0.033 & -0.112 & -0.053 & 0.037 & -0.042 & 0.073 & 0.239 & 1.000 & & & & & \\
\hline Sep & 0.071 & 0.017 & -0.084 & 0.100 & 0.051 & 0.200 & 0.249 & 0.051 & 1.000 & & & & \\
\hline Octo & -0.008 & -0.023 & $0.451^{* *}$ & 0.083 & 0.087 & 0.152 & 0.128 & 0.053 & 0.019 & 1.000 & & & \\
\hline Nov & 0.019 & -0.098 & -0.113 & -0.207 & -0.221 & -0.120 & 0.064 & 0.184 & $0.403^{* *}$ & -0.142 & 1.000 & & \\
\hline Dec & 0.236 & -0.058 & $0.507^{* *}$ & 0.044 & 0.179 & -0.010 & -0.064 & -0.147 & -0.131 & $0.272^{*}$ & -0.093 & 1.000 & \\
\hline Total & 0.140 & -0.013 & 0.251 & $0.318^{*}$ & 0.230 & $0.620^{* *}$ & $0.656^{* *}$ & $0.469^{* *}$ & $0.524^{* *}$ & $0.440^{* *}$ & 0.085 & 0.058 & 1.000 \\
\hline
\end{tabular}

*. Correlation is significant at the 0.05 level (2-tailed).

**. Correlation is significant at the 0.01 level (2-tailed).

The total amount of annual rainfall is strongly significantly positively correlated with the total monthly rainfall of the months of June, July August, September and October and significantly positively correlated with the total monthly rainfall of the month April (Table 3). This study reveals that the total annual rainfall is mainly influenced by the total amount of monsoon rainfall. The heavy rainfall in May-September is suggestive that the study area is located in humid tropical area and the rainfall is influenced by the South West Monsoon. The amount of pre-monsoon rainfall also influences the total annual rainfall of Rangpur. On an average 18.67\% rainfall of the year occurs in Pre-monsoon periods. The importance of pre-monsoon period is increasing day by day with the increased cultivation of rice in this time span. The Pearson correlation matrix index of daily rainfall and mean daily temperature (of July, 1987) shows that they are significantly negatively correlated. This result suggests that the daily temperature in Rangpur during the summer monsoon is controlled by the amount of rainfall.

\section{Conclusion}

The trend of annual rainfall is increasing and the mean annual rainfall is $2099.25 \mathrm{~mm}$. The maximum amount of rainfall is recorded during the summer monsoon. The total annual rainfall is significantly positively correlated with the monsoon rainfall. The analysis shows that it rained in every year in the month of June as the minimum monthly value for June is greater than zero. The climate change can be revealed by the increment of pre-monsoon rainfall especially in the month of May. May is the harvesting time of paddy in Rangpur. The heavy rainfall in May might have impact on the production of rice. The daily temperature in the summer months lowered by the amount of daily rainfall in those months. In Rangpur, the value of skewness for all rainfall data are positive that indicate the data are skewed to the right. The positive values of kurtosis indicate that the distribution is not normal. Further research works can be taken on the seasonal variability of chemical composition of ground and surface waters and the change in groundwater levels.

\section{Conflict of interest statement}

Author does not have any conflicts of interest.

\section{Acknowledgement}

The author is pleased to thank the people who assisted, inspired and encouraged during the research work.

\section{References}

[1] Hussain MM, Abdullah SKM (2001) Geological Setting of the Areas of Arsenic Aquifers, Ground Water Task Force, Interim Report No.1, Local Government Division, Ministry of Local Government, Rural Development \& Cooperatives, Bangladesh, pp. A 1-A 45. http://fineprint.com.

[2] IPCC (2014) Climate Change 2014: synthesis report. In: Core Writing Team, Pachauri R.K., Meyer L. A. (eds) Contribution of working groups I, II and III to fifth assessment report of the Intergovernmental Panel on Climate Change. IPCC, Geneva.

[3] Islam, M., Imon, T.I. and Polash, A. G., 2019, Analysis of Rainfall Variability in Sylhet Region of Bangladesh: Journal of Water Resource Engineering and Management, v.6 (2), pp. 1-10.

[4] Rahman, M.A., Yungsheng, L. and Sultana, N., 2016, Analysis and prediction of rainfall trends over Bangladesh using Mann-Kendall, Spearman's rho tests and ARIMA model: Meteorol. Atmos Phys, https://doi.org/10.1007/s00703-016-0479-4.

[5] Richard, S.J.T. 2012, the economic impact of climate change in the $20^{\text {th }}$ and $21^{\text {st }}$ centuries: Climate Change, v 117(4), pp.795-808. https://doi.org/10.1007/s10584-012-0613-3.

[6] Saha S., Reza, A.H.M.S. and Roy M.K., (2020) Illite crystallinity index an indicator of physical weathering of the Sediments of the Tista River, Rangpur, Bangladesh: International Journal of Advanced Geosciences, 8(1): 27-32. https://doi.org/10.14419/ijag.v8i1.30551.

[7] Saha S., Reza, A.H.M.S. and Roy M.K., 2019 Hydrochemical evaluation of the groundwater quality of the Tista floodplain, Rangpur, Bangladesh: Applied Water Science, 9,198. https://doi.org/10.1007/s13201-019-1085-7.

[8] Shahid, S. 2010, Rainfall variability and the trends of wet and dry periods in Bangladesh: International Journal of Climatology, v.30 (15), pp. 2299 2313. https://doi.org/10.1002/joc.2053.

[9] Shahid, S. and Khairulmaini O.S. 2009, Spatio-temporal variability of rainfall over Bangladesh during the time period 1969-2003: APJAS, v.45 (3), pp. 375-389.

[10] UNDP (United Nations Development Programme) (1982) Groundwater survey: The hydrogeological conditions of Bangladesh. UNDP Technical Report DP/UN/BGD-74-009/1. 